Trivent Publishing

(C) The Authors, 2015

Available online at http://trivent-publishing.eu/

Philosophy, Communication, Media sciences Series

Volume Saint Gerard of Cenad: Tradition and Innovation

\title{
Western Biblical Studies in the Work of Roman-Catholic and Orthodox Theologians 1867-1918
}

\author{
Alin Cristian Scridon \\ West University of Timisoara, Faculty of Letters, History and Theology, Romania, alin.scridon@e-uvt.ro
}

\begin{abstract}
During the dualistic period (1867-1918), the historical Banat region in Romania had two active Churches: the Roman-Catholic and the Orthodox churches. Of course, there were also Greek-Catholic and Protestant (Lutheran and Calvin) churches, but most Christians belonged to the Roman-Catholic and Orthodox communities. Because of ethnical separations, the orthodox were further divided into the Romanian Orthodox Church and the Serbian Orthodox Church. The Romanians of Banat were led by two Bishopric Centres: Caransebes and Arad. Both bishoprics were canonically dependent on the Transylvanian Metropolitan Church with its headquarters in, Sibiu. The Roman-Catholic Bishopric of Timisoara led valuable activities, having a clerical school in its jurisdiction. Therefore, historical Banat had three theological study centres: Arad, Caransebes, and Timisoara-although Arad was not officially part of the historical Banat.
\end{abstract}

\section{Keywords}

The Diocesan Theological Institute of Caransebeş; the New Testament; the Bible; Theology; Church.

This work was supported by the strategic grant POSDRU/159/1.5/S/140863, Project ID 140863 (2014), co-financed by the European Social Fund within the Sectoral Operational Program Human Resources Development 2007-2013.

This is an Open Access article distributed in accordance with the Creative Commons Attribution Non Commercial (CC-BYNC-ND 4.0) license, which permits others to copy or share the article, provided original work is properly cited and that this is not done for commercial purposes. Users may not remix, transform, or build upon the material and may not distribute the modified material (http://creativecommons.org/licenses/by-nc/4.0/)

DOI: 10.22618/TP.PCMS.20151.176011 
On the $23^{\text {rd }}$ of September 1865, the Romanian Theological Institute of Caransebes (the sector transferred from Vârşeţ in Serbia) started its classes, while the Theological Institute of Arad was founded in $1822{ }^{1}$

In the Theological Institute of Caransebes, several renowned professors in the Habsburg Empire and Romania taught classed on the New Testament. Iosif Iuliu Olariu (1859-1920) was one of them. He published, in 1894, the thesis titled Manual exegetic la Sfânta Scriptură a Testanmentulŭ nou. Evangheliile după Matei, Marcu şi Luca comentate de Iuliu Olariu. The book is well documented and extremely thick (644 pages) for those times. By the end of the work, Iosif Iuliu Olariu makes the following remark:

I made the translation on the Tischendorf text, corrected by O. V. Gebheardt (Novum Testamentum graece ex ultima Tischendorfii recensione, edito stereotype minor, Lipsiae 1887. B. Tauchnitz) blending with Vulg. Rec. and Romanian translation (of Bucharest, Blaj, Buzau, Saguna). ${ }^{2}$

Furthermore, Iosif Iuliu Olariu also studied the latest exegetic literature: Carl Friedrich Keil, Frederick Brotherton Meyer, Hermann Olshausen, Johannes Weiss, Peter Schegg, etc. Iosif Iuliu Olariu closed the exegetic circle of the gospels by publishing the exegetic work of the Gospel of John in 1897 (although the cover bears the year 1898) in Caransebes at the Diecezana Printing House. In the foreword of this study, written in the Feast of the Cross (the $14^{\text {th }}$ of September) in the year 1897, Olariu noted that he used the same bibliographical sources (especially German) used in the synoptics, and in the work published three years earlier. ${ }^{3}$

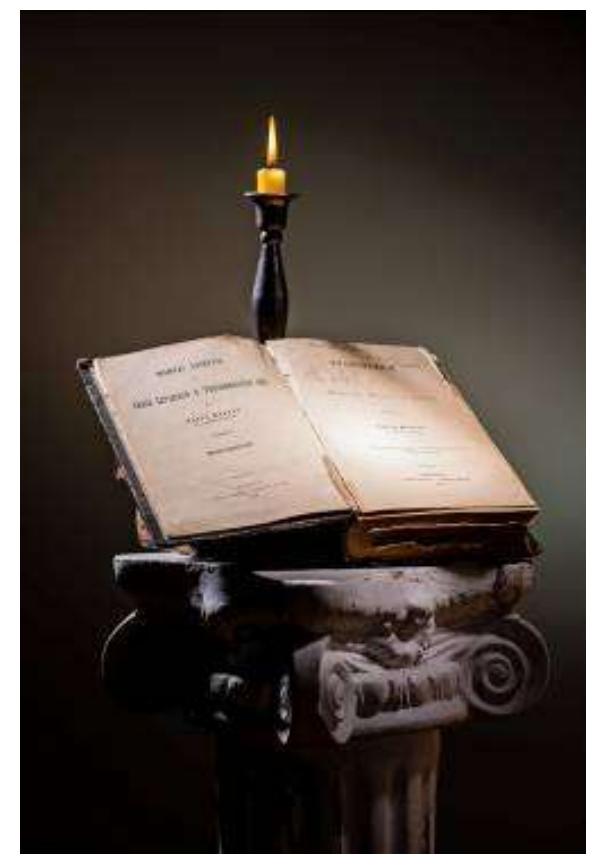

Fig. 1. Exegetics manual for the Holy Scripture of the New Testament. Gospel of Matthew, Mark, and Luke commented by Iuliu Olariu.

\footnotetext{
${ }^{1}$ Pavel Vesa, Învăţământul teologic de la Arad 1822-1948 [Theological Education in Arad 1822-1948], (Deva: Editura Episcopiei Devei şi Hunedoarei, 2013), 11.

${ }^{2}$ Iuliu Olariu, Manual exegetic la sfânta Scriptură a Testanmentuluĭ noŭ. Evangheliile după Mateiŭ, Marcu şi Luca comentate de Iuliu Olariu, volumul I, Sinopticii [New Testament Exegesis. The Gospels of Matthew, Mark and Luke], (Caransebeş: Tipografia Diecezană, 1894), V.

${ }^{3}$ Iuliu Olariu, Evanghelia după Ioan explicată de Dr. Iuliu Olariu [Gospel of John explained by Dr. Iuliu Olariu], (Caransebeş: Tipografia Diecezană, 1897).
} 


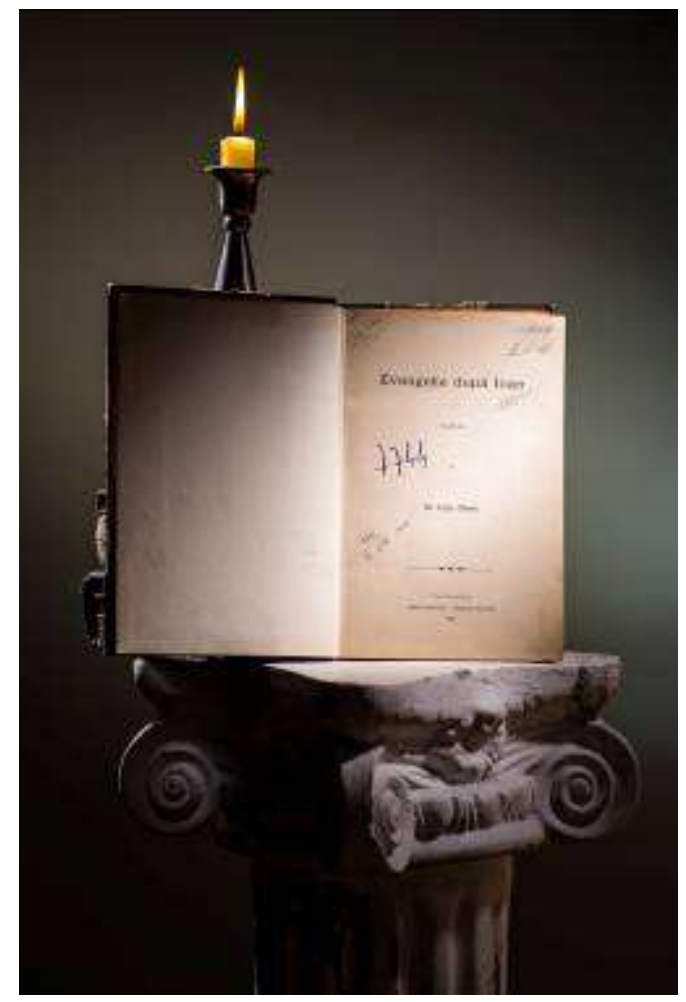

Fig. 2. Gospel of John explained by Dr. Iuliu Olariu

The turn of the nineteenth century represented a prolific period for Olariu's work. Every second to fourth year, he published a vast piece of work, which entered the scientific circuit, but which was most helpful to theRomanian students of theology, given that they could not access the information before because of the language barrier. Therefore, in 1901, the Diecezana Printing House of Caransebes published his Explicarea Psalmilor din Ceaslov de Dr. Iuliu Olariu. This scientific endeavour was based on the theory that "the Psalter plays an important part in the godly cult of the Orthodox Church, which can be seen more clearly in the fact that the Fathers comment on it and praise it a numerous times." ${ }^{4}$ Furthermore, Olariu also addressed the Psalms in order to "enable the understanding of the psalms which are used in divine service, as they are placed in the Horologe."

This work on the Psalms was based on western exegetical sources and authors such as Valentin Thalhofer, Peter Schegg, Franz Delitzsch, Ernst Wilhelm Hengstenberg etc. ${ }^{6}$ The results and analyses on these works were brought into the Romanian space with the help of Iosif Iuliu Olariu.

\footnotetext{
${ }^{4}$ Iuliu Olariu, Explicarea Psalmilor din Ceaslov de Dr. Iuliu Olariu [Explanation of the Psalms of Ceaslov by Dr. Iuliu Olariu], (Caransebeş: Tipografia Diecezană, 1901), 3.

${ }^{5}$ Ibidem.

${ }^{6}$ Ibidem
} 


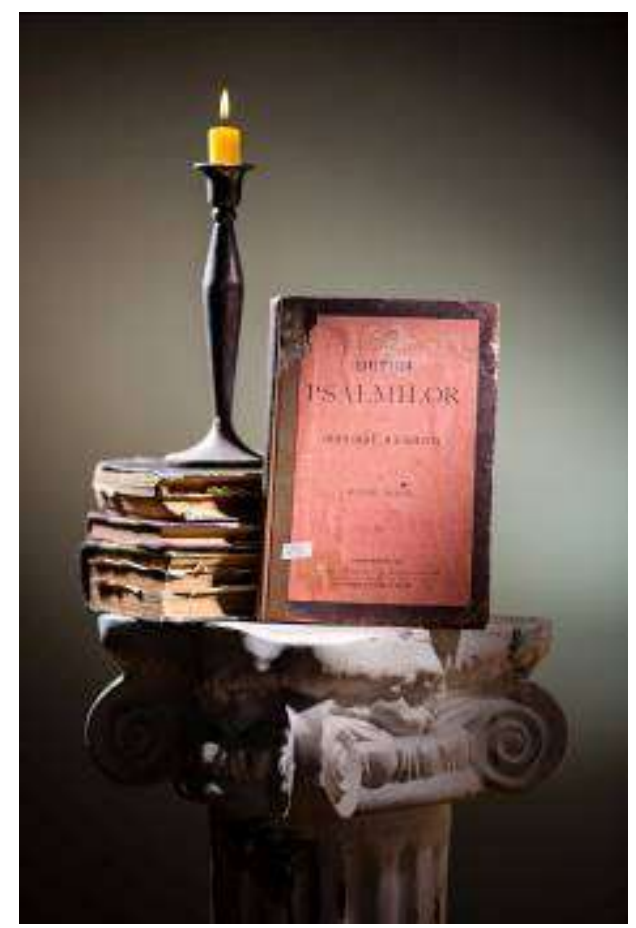

Fig. 3. Explanation of the psalms of the Horologion by Dr. Iuliu Olariu

The editorial debut of Olariu came with "Introduction to the Old and New Testament books (Introducere în cărţile sânte ale T.V. şi $N$ de Dr. I. Olariu) The book was published at the Diecezana Printing House in 1891, expanding over 381 pages $(23 \mathrm{x} 15,5){ }^{7}$ The first major work of the biblical scholar from Caransebes revealed the fundamental elements of biblical isagoge to the Romanian public, all of which which are essential to theologians. of the work is written from a historical-critical perspective. In preparing his thesis, Olariu used the theological works of Karl August Credner, Édouard Guillaume Eugène Reuss, Wilhelm Martin Leberecht de Wette, Clement Schrader, etc. Moreover, professor Isidor of Onciul from Cernauti had a significant role in shaping the book.

Another theologian from Caransebes, Petru Barbu (1864-1941), highlighted the fact that he used western theology works when completing his books - such as Henri Louis Rémy Didon and the German Constantin von Tischendorf. The book Jesus Christ with the words of the holy scriptures (Isus Cristos cu cuvintele sântei scripturi) is the largest biblical research of professor Petru Barbu.

Before presenting the life of Christ in his 173 pages, the author justifies the purpose of his study in the preface:

The Lord and Saviour of our world Jesus Christ, Son of God, is the founder of our church. It's not possible to be a true member of this churchunless you know the earthen life of its founder. (...) In chronological stringing moments of the life of Jesus and the establishment of parallel places we kept in mind the thinking of the exegets and the authors of the Savior's life, especially the authors R. P. Didon (Romanian translation) and I.B. Lohmann. The text is of the spoken Bible in the righteous Romanian church and it's related to the Greek one (Tischendorf ed. XX). At this place I bring thanks to those Christians that, subscribing my book, rushed her reading. ${ }^{8}$

\footnotetext{
${ }^{7}$ Petru Călin, Tiparul românesc diecezan din Caransebeş, 1885-1918, vol. 1 [Romanian Diocesan Printing of Caransebeş],(Reşiţa: Banatica, 1996), 77-78.

${ }^{8}$ Petru Barbu, Isus Cristos cu cuvintele Sântei Scripturi [Jesus Christ in the Words of the Holy Scripture], (Caransebeş: Tipografia Diecesană, 1902), II.
} 
On the other hand, the Roman-Catholic favored the theological Diecezan Institute from Timisoara. The analysis of existing documents in the archive of Roman-Catholic Bishopric shows that in every decade since the second half of the nineteenth century, the number of students has been increasing as shown in the table below.

Table 1. Number of students enrolled in the Theological Seminary of Timisoara during 1875, 1886, 1896, and $1913^{9}$

\begin{tabular}{|c|c|c|c|c|c|}
\hline \multirow{2}{*}{ Year } & \multicolumn{5}{|c|}{ Number of students } \\
\cline { 2 - 6 } & Year I & Year II & Year III & Year IV & Total \\
\hline 1875 & 8 & 4 & 6 & 6 & 24 \\
\hline 1886 & 16 & 12 & 11 & 9 & 48 \\
\hline 1896 & 16 & 14 & 8 & 9 & 47 \\
\hline
\end{tabular}

During the Austro-Hungarian dualist period at the Theological institute, New Testament studies were taught by the theologians Johann Nep. Engels (1866-1868), Josef Grosz (1869-1883), Stefan Patzner (1884-1885), Matthias Palmer (1885-1887), Franz Blaskovics (1887-1894), Matthias Ferch (1895-1899), Emerich Pager (1900-1902), GeyzaSzanthó (1902-1909), Aurel Martin (1909-1914), Matthias Ferch (1914-1919) ${ }^{10}$ - all with higher education degrees in European universities.

While Orthodox theologians benefited from scholarship programs, more so did the RomanCatholics. Only one of nine teachers of the Department of Bible studies did not study abroad. All the rest benefited from western education. The table below shows the higher education institutes attended by the Roman-Catholic students from Timisoara.

Table 2. Teachers of New Testament studies from the Diecezan Institute. University and graduation year ${ }^{11}$

\begin{tabular}{|c|c|c|}
\hline Years of study & University & Student name \\
\hline $1889-1892$ & Budapest (Austro-Hungary) & Matthias Ferch \\
\hline $1900-1905$ & $\begin{array}{c}\text { Budapest (Austro-Hungary) } \\
\text { Freiburg (Germany) } \\
\text { Löwen (Belgium) }\end{array}$ \\
\hline $1906-1907$ & Vienna (Austria) & Johann Nep. Engels \\
\hline $1904-1906$ & Vienna (Austro-Hungary) & Stefan Patzner \\
\hline $1862-1866$ & Vienna (Austro-Hungary) & Matthias Palmer \\
\hline $1881-1882$ & Vienna (Austro-Hungary) & Franz Blaskovics \\
\hline $1882-1886$ & Vienna (Austro-Hungary) & Emerich Pager \\
\hline $1888-1892$ & Innsbruck (Austria) & Josef Grosz \\
\hline $1862-1868$ & & \\
\hline
\end{tabular}

Of the Roman-Catholic theologians who taught New Testament studies at the Theological School in Timisoara, Josef Grosz was distinguished for publishing two papers on isagoge in Biblical Studies, in the late nineteenth century. The Isagoge of Old Testament written by Josef Grosz was published in $1879^{12}$ and that of the New Testament, one year later, in $1880 .{ }^{13}$

\footnotetext{
9 A.E.R.C.T., Schematismus Cleri Diocesis Csanadiensis pro Anno Domini, MDCCCLXXV, Temesvárini, Typographiae Dioecesis Csanádiensis, 1875, p. 174; Ibidem, 1886, p. 210; Ibidem, 1896, p. 207-208; Ibidem, 1913, p. 251.

${ }^{10}$ A.E.R.C.T., Neue Banater Bücherei..., p. 3.

${ }^{11}$ Idem, p. 10-11.

${ }^{12}$ Josef Grosz, Introductio in libros sacros Veteris Testamenti, Typis Dioecesis Csanadiensis, Timişoara, 1879.

${ }^{13}$ Idem, Introductio in libros sacros Novi Testamenti, Typis Dioecesis Csanadiensis, Timişoara, 1880.
} 
Therefore, when studying the writings on the New Testament, from the second half of the nineteenth century to the first decades of the twentieth century in the historical region of Banat in Romania, one can notice an effervescent activity on this Roman-Catholic and Orthodox territory. One may say that the two lungs of the universal Christianity, Roman-Catholicism and Orthodoxy as developed in Banat, made significant contributions to the Biblical studies.

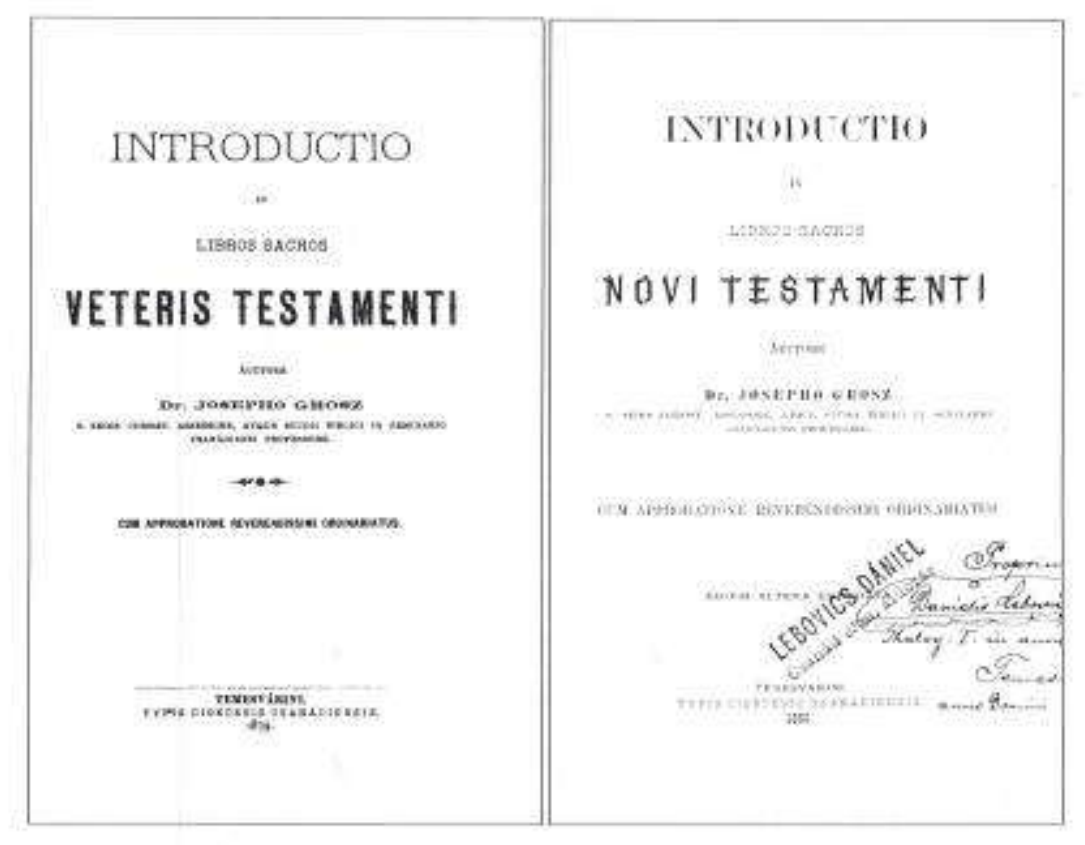

Fig. 4.The Isagoge works published by Josef Grosz in the late nineteenth century

\section{References}

Arhiva Episcopiei Romano-Catolice din Timişoara [Archives of the Roman Catholic Diocese of Timişoara] (A.E.R.C.T.). Schematismus Cleri Diocesis Csanadiensis pro Anno Domini. Timişoara: Typis Ernesti Steger, 1875, 1886, 1896, 1913.

Barbu, Petru. Isus Cristos cu cuvintele Sântei Scripturi [Jesus Christ in the words of the Holy Scripture]. Caransebeş: Tipografia Diecezană, 1902.

Călin, Petru. Tiparul românesc diecezan din Caransebeş [The Romanian Diocesan Printing of Caransebeş]. Reşiţa: Banatica, 1996.

Grosz, Josef. Introductio in libros sacros Veteris Testamenti. Timişoara: Typis Dioecesis Csanadiensis, 1879.

. Introductio in libros sacros Novi Testamenti. Timişoara: Typis Dioecesis Csanadiensis, 1880.

Olariu, Iuliu. Exegeza Noului Testament. Evangheliile după Matei, Marcu şi Luca [New Testament Exegesis. The Gospels of Matthew, Mark and Luke]. Caransebeş: Tipografia Diecezană, 1894.

Evanghelia după Ioan explicată de Dr. Iuliu Olariu [Gospel of John explained by Dr. Iuliu Olariu]. Caransebeş: Tipografia Diecezană, 1897.

Explicarea Psalmilor din Ceaslov de Dr. Iuliu Olariu [Explanation of the Psalms of Ceaslov by Dr. Iuliu Olariu]. Caransebeş: Tipografia Diecezană, 1901.

Vesa, Pavel. Invăţământul teologic de la Arad (1822-1948) [The theological Education in Arad (1822-1948)]. Cluj-Napoca: Presa Universitară Clujeană, 2013.

All photographs were taken by the author. 